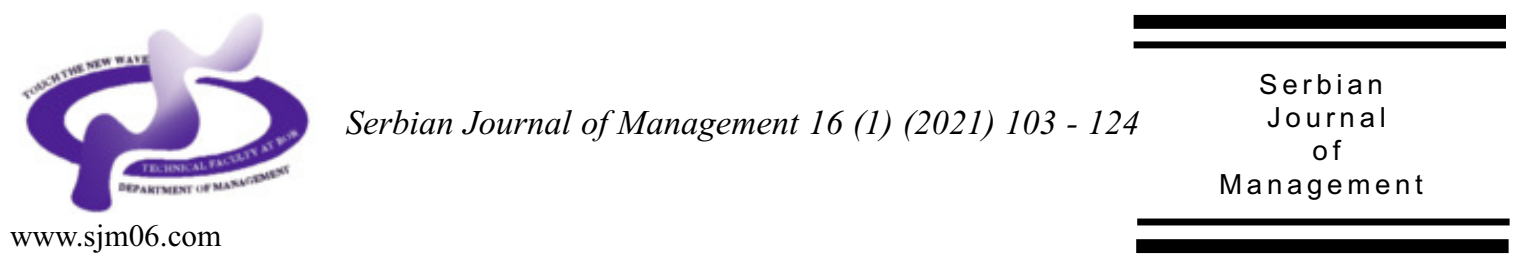

\title{
THE ERA OF SHARING ECONOMY: FACTORS THAT INFLUENCE THE BEHAVIORAL INTENTIONS OF USER AND PROVIDER TO PARTICIPATE IN PEER-TO-PEER SHARING ECONOMY
}

\author{
Aleem Raza*, Muhammad Asif and Samia Ayyub \\ University of Veterinary and Animal Sciences, UVAS Business School, \\ Lahore 54000, Pakistan
}

(Received 18 December 2019; accepted 30 June 2020)

\begin{abstract}
The Sharing Economy is a fastest growing and heavily debated Socio economic model. In the platform-based sharing economy, the provider provides the service and the consumer using the service from a two-sided market. However, there is a lack of studies that cover the both sides of platform based sharing market. This study aims to examine the effect of Indulgence, trust, economic benefit, social interaction, enjoyment and sustainability on user and provider intention to engage in peer-to-peer sharing. This explanatory study uses a quantitative methodology involving data collection through structured questionnaire from service users $(n=220)$ and service providers $(n=170)$ of Uber and Careem by adopting snowball sampling technique. Structured Equation Modeling (SEM) was applied to analyze data by using AMOS 24. The empirical results of this study indicate that indulgence, social interaction, economic benefit and enjoyment have significant positive association with user and provider intention. Further, a positive relationship was found between provider trust in user and provider intention to engage in peer-to-peer sharing. This study makes its significant contribution by providing new insights to literature and practice by studying two sided market. In addition the study explored the effect of indulgence on peer-to-peer sharing intention which is found yet to be explored in the literature. This study suggests practical implications for the Marketing managers to develop effective platform business strategies and marketing campaigns in accordance with the individuals' intention to engage in sharing.
\end{abstract}

Keywords: sharing economy, peer-to-peer sharing, intention, indulgence, sustainability, economic benefits, social interaction

\footnotetext{
*Corresponding author: aleemraxa@outlook.com
}

DOI: $10.5937 /$ sjm16-24481 


\section{INTRODUCTION}

In the aftermath of the global economic recession in 2008, the economic concept called "sharing economy" has captured the attention for the development of network and communication technologies by challenging the conventional thinking about how idle resources should be provided and consumed (Perfili et al., 2019). With this technological development, the business and economic system brings innovation in the consumption model by changing it from personal possession to the goal of shared access to products and services (Lamberton \& Rose, 2012; Cheng, 2016; Hamari et al., 2016; Habibi et al., 2017). The sharing economy has been appeared as contemporary economic model which can be defined as uncommon social and economic interactions that collectively shares assets with other people to decrease lavish and primarily gives the rise of ordinary interest in society (Belk, 2007). This is a phenomenon in which the consumers act as sellers giving services that were provided by professional sellers (Sundararajan, 2016). Sharing economy reaches the new heights by providing individuals the opportunity to earn from their underutilization resources, as reported by Hathaway and Muro (2016), in United States the number of non-employer occupation has increased from 15 million in 1997 to approximately 24 million in 2014 (Yaraghi \& Ravi, 2017). Researchers at price water house cooper studied and estimates that within the Ten years, the most important sharing sectors, including peer-to-peer sharing, online staffing, car sharing, sharing the accommodation and music streaming will make more than half of the total worldwide income (PwC, 2015). The global revenue of sharing economy will grow to
US $\$ 335$ billion by the end of 2025, compared with US\$15 billion in 2015 (PwC, 2015). The United Kingdom national statistics office found that in 2016, more than 270 European sharing platforms caused \$5 billion (Yaraghi \& Ravi, 2017).

Sharing economy is turned into prevalent proceeding in multiple fields. Hospitality, transport, and retailing are the examples of those areas which are affected by sharing economy. With significant growth, the sharing economy provide a chance to households, individuals, businesses and other non-government or government associations to engage in collaborative process of production, distribution and utilization (Stokes et al., 2014). "Collaborative consumption" (Botsman \& Rogers, 2010) "access-based consumption" (Bardhi \& Eckhardt, 2012) and "commercial sharing systems" (Lamberton \& Rose, 2012) are the concepts which are subsumed under the parasol of sharing economy. Within the scope of this research work, we spotlight a particular concept of peer to peer exchange, which also comes under the parasol of sharing economy. The sharing economy is predominantly characterized by peer-to-peer exchanges for renting goods and services using digitalized platforms (Ganapati \& Reddick, 2018). In transportation sector Uber is an example of providing transportation services by employing the unused resources of common car owners. Uber started its business in 2009 and became an entrenched transportation option today valued at US\$ 68 billion, which is greater than of Chrysler, Ford, and General Motors (Chen, 2015).The consumers can travel at cheap rates than other transportation options and it is significantly more economical than owning a vehicle. For instance supplier and providers in Uber or Careem (Middle 
Eastern company operating in Pakistan and other countries) can join in or opt out with just a few clicks.

The continuous rise in gig economy has changed the consumer's behavior and mentalities in online context. The consumers are concerned about participation in peer-topeer exchange, trading their unused or underutilized resources with unknown individuals or groups (Botsman \& Rogers, 2010). Today advanced technological innovation and increase in usage of smart phones and market expansion has covert this phenomenon of sharing economy into a business model able to achieve economies at large scale (Belk, 2007), by providing consumer multiple options to search for providers at lower cost on sharing platforms (Zervas et al., 2017). Peer-to-peer sharing continues to emerge around the globe, some researchers have anticipated that peer-to-peer sharing could be as big as the industrial revolution (Cusumano, 2015). In previous studies, researchers have studied either the user or provider with regard to encouraging aspects of sharing economy (Böcker \& Meelen, 2017; Mao \& Lyu, 2017; Liang et al., 2018). But it is not a complete strategy to understand the sharing economy by studying only user's intention or studying only the causes of participation of service provider in peer-to-peer sharing. When a service provider provides services to the user through platform-based sharing, it results in formation of two-sided or multi-sided markets. Where service provider and user interacts over the platform and the value of platform rises with the size of network (Rysman, 2009). There are few studies which considered the both user and provider sides in peer-to-peer sharing (Hawlitschek et al., 2016a; Sung et al., 2018; Gupta et al., 2019), still more empirical research is required to develop understanding regarding service user and service provider interaction and factors influencing this interaction in sharing economy. This study provides a unified model to study the provider's and user's intention to engage in sharing economy.

This research contributes to the province of sharing economy by examining those factors which leads to influence the mentalities of service providers and service consumers in peer-to peer sharing. To address the concerns related to the need of quantitative research in field of sharing economy and providing deep understanding to marketers, we investigate the impact of influential factors on people intention to provide service and to consume service using peer-to-peer sharing. In addition, this research studies the role of Indulgence as cultural value in forming the intention to use and provide services in peer-to-peer sharing.

\section{LITERATURE REVIEW}

\subsection{Role of peer-to peer sharing economy in developing countries}

In context of developing nations, besides the economic and financial challenges there is one social problem related to the bad transportation system. For instance, in Pakistan many people who travels on a daily basis, have to use public transport due to less availability of alternatives. Recently, the government has also launched new bus transport services in different cities but still there is a need of the society regarding transportation system. In such circumstances, peer-to-peer sharing economy has the potential to solve social, financial and economic issues in developing countries. In less developed countries with 
bad transportation services, ride sharing can provide good transport services to people without the need of having their own vehicle. According to Brookings India report (Villasenor et al., 2015), private vehicles go unused for $95 \%$ of their lifetime which could be used to reduce the overburdened public transport especially in mass populated regions such as India and Pakistan. The citizens in such countries can benefit from lower costs, better transport services and timely access to work. Considering the socio-demographic differences, individuals who are younger and have low income are more influenced from financial and economic perspective (Sung et al., 2018). On the other side, sociability and motivation to protect the environment where they live are important factors that lead toward individuals' participation in peer-to-peer sharing economy (Hawlitschek et al., 2016a).

\subsection{Peer-to peer sharing}

\section{Table 1. Definitions of the Sharing economy}

\begin{tabular}{ll}
\hline Source & Definition \\
\hline (Heinrichs, 2013) & $\begin{array}{l}\text { In sharing economy, people exchange, share, rent out and rent the } \\
\text { products, services and expertise. }\end{array}$ \\
The sharing economy leads to minimize the ownership of assets by \\
making them available online to a group. \\
The on-demand economy refers to connecting consumers to \\
services through on internet platforms through mobile application.
\end{tabular}

The concept of sharing is not entirely new. In the previous decades, the sharing economy has occurred as alternative to the capitalist economy by enhancing collaborative consumption. Today, the use of information technology, establishing formal platforms and networks has brought newness to the sharing concept. With the passage of time, the collaborative consumption is inevitably becoming a significantly growing sector of global economy. The present day sharing economy is defined as peer-to-peer sharing of goods and services through internet platforms (Albinsson \& Yasanthi Perera, 2012). Researchers have defined the sharing economy to many extents (Cheng, 2016), and used alternative names for the sharing economy, such as collaborative consumption (Botsman \& Rogers, 2010), gig economy (Mulcahy, 2016), mesh economy (Gansky, 2010), platform economy (Parker et al., 2016) and on-demand economy (Ganapati \& Reddick, 2018). There is considerable discrepancy in the way researchers have defined this phenomenon. 
The multiple definitions of sharing economy from literature are given in the Table 1 .

As a result, the researchers describe the sharing economy or collaborative consumption as an umbrella construct, i.e. a comprehensive notion used to cover a wideranging phenomenon (Hirsch \& Levin, 1999). The concept of peer-to-peer sharing has captured the attention across diversified academic areas (Lamberton \& Rose 2012; John, 2013). Different studies have found out the factors which motivate the people to participate in sharing economy. These studies have shown several reasons, such as hedonic, social and economic benefits can motivate the consumer (Botsman \& Rogers, 2010; Möhlmann, 2015), and the provider to participate in sharing economy (Bucher et al., 2016, Böcker \& Meelen, 2017). The factors which affect the intentions of consumer and provider to engage in collaborative consumption are summarized in Table 2.

There are only a few studies on providers' intention to engage in collaborative consumption. For instance, (Karlsson \& Dolnicar, 2016) found that social interaction, Income and Sharing experience are the main factors which motivate the provider to share accommodation. (Sung et al., 2018) found the economic incentive, social relation, enjoyment, sustainability and network effect as motives for participation in peer-to-peer sharing. In addition (Gupta et al., 2019) studied the effect of cultural value on intention to engage in sharing economy. Still there is a need of studies examining and understanding the reason for participation in sharing economy from a provider's angle, Therefore this study provides a better understanding regarding these aspects.

\subsection{Trust}

In consumer's perspective trust is an instinctive feeling that the providing peer will fulfill the transactional responsibility (Kim et al., 2009) and provider is considered as the transaction ally of high morality and altruism (Pavlou \& Fygenson, 2006). Trust

Table 2. Previous studies from provider and user perspective

\begin{tabular}{ll}
\hline \multicolumn{1}{c}{ Constructs } & \multicolumn{1}{c}{ From User viewpoint } \\
\hline \multicolumn{1}{c}{ Researcher } \\
\hline $\begin{array}{l}\text { Economic Benefit, Sustainability, Enjoyment, Social Relationship, } \\
\text { Collectivism, Masculinism, Uncertainty Avoidance, Power Distance }\end{array}$ & (Sung et al., 2018) \\
$\begin{array}{l}\text { Subjective norms, perceived value, perceived behavioral control, } \\
\text { unique experience expectations, familiarity, eWOM }\end{array}$ & (Mao \& Lyu, 2017) \\
$\begin{array}{l}\text { Enjoyment, Independence through ownership, Modern style and } \\
\text { social experience, }\end{array}$ & (Hawlitschek et al., 2016) \\
$\begin{array}{l}\text { Trust and utility, Cost savings, Familiarity } \\
\text { Price sensitivity }\end{array}$ & (Möhlmann, 2015) \\
\hline \multicolumn{1}{c}{ From Provider viewpoint } \\
$\begin{array}{l}\text { Collectivism, Masculinism, Uncertainty avoidance, Power Distance } \\
\text { Economic Benefit, Sustainability, Enjoyment, Social Relationship, } \\
\text { Network effect }\end{array}$ & (Gupta et al., 2019) \\
$\begin{array}{l}\text { Income, Enjoyment, Product variety, Social experience, Social } \\
\text { influence }\end{array}$ & (Sung et al., 2018) \\
Social, Economic, Environmental Motivators & (Hawlitschek et al., 2016) \\
\hline
\end{tabular}


plays vital role in influencing the consumer's intention in uncertain situations (Kim et al., 2009). Based on "commitment-trust theory of relationship marketing" by Morgan and Hunt, trust is the prognosticator of any shared activity (Morgan \& Hunt, 1994) the consumer satisfaction and chance of choosing the sharing service again depends on the trustworthiness (Möhlmann, 2015) in such context of cooperation, when user perceive the provider trustworthy, chances of user's engagement in sharing economy and completing a transaction will be high (Leonard, 2012; Hawlitschek et al., 2016b). Thus, it is hypothesized that:

H1(a): Trust in provider will positively affect the user intention to engage in peer-topeer sharing.

As peer-to-peer sharing is built on the interactive contract of completing a transaction, therefore the provider's trust in the user is also of great importance. In peerto-peer sharing, when peer provider provides the services or share resources (car, bike, house or other resources) with the user, the provider has no control over resources for agreed time period. Therefore the main barrier in sharing from provider's perspective is getting worried about damage to shared resources due to some unseen actions by the user (Weber, 2014). It means that the provider's trust in user peer is the principal reason of provider's participation in collaborative consumption (Teubner et al., 2014). Completion of rental transaction is hard to achieve without the provider's trust in user peer (Hawlitschek et al., 2016b). Therefore, it is hypothesized that:

H1(b): Trust in user will positively affect the provider intention to engage in peer-topeer sharing.

\subsection{Economic benefit}

As a result of global financial crises 2008, the consumer's behavior has been changed. They are more concerned about spending their money and usage of available resources (Gansky, 2010; Chudzian, 2015; Tussyadiah, 2015). More than 80 percent of the US consumers consider that shared products are less costly ( $\mathrm{PwC}, 2015)$, which indicates that cost benefit is an important driver of user participation in sharing economy. Consumers can save their time and money by acquiring goods and services from peer-topeer sharing (Barbu et al., 2018). Mohlmann M. found in his study that savings increases the probability of satisfaction with the service provided (Möhlmann, 2015). In peerto-peer sharing lesser the expense, more the consumer will be motivated to engage in sharing (Bardhi \& Eckhardt, 2012). Most of the studies have found the positive impact of economic benefit on attitude and intention to participate (Hamarit et al., 2016; Sung et al., 2018). Based on findings of these studies we can formulate the hypothesis as:

H2(a): Economic benefit will positively affect the user intention to engage in peer-topeer sharing.

Previous studies on sharing economy points to the fact that economic benefits is one of the major causes of provider's participation in sharing activity (Bardhi \& Eckhardt, 2012; Lamberton \& Rose, 2012). According to Chui et al., (2012) the sharing economy increases the financial flexibility of owner to earn money and gain financial benefits by sharing idle resources. Researchers found in their studies that economic benefits is the main reason of providing services in sharing economy (van 
de Glind, 2013; Guttentag et al., 2018). Therefore it is suggested that providers who perceive that providing service or product will bring them economic advantages are more likely to engage in peer-to-peer sharing.

H2(b): Economic benefit will positively affect the provider intention to engage in peer-to-peer sharing.

\subsection{Sustainability}

Globally, with growing concern for environmental issues, sustainability implications of consumer and their consumption pattern have captured the attentiveness of researchers (Huang \& Rust, 2011; Prothero et al., 2011). Previous research indicate that how peer-to-peer sharing positively effects sustainability by sharing consumer resources instead of owned by individuals (Bartenberger \& Leitner, 2013). In North America, Average greenhouse gas emissions are reduced by sharing a car (Martin \& Shaheen, 2011). It is suggested that ridesharing allow the consumers to save resources and decreases the vehicle ownership (Efthymiou et al., 2013). In PwC's survey report, more than 76 percent of the respondents stated that peerto-peer Sharing is beneficial for the nature (PwC, 2015).

Sharing economy can be observed as indication of sustainable behavior with a desire to become environmentally responsible individual (Tussyadiah, 2015). Sharing economy is appearing as a new phenomenon that can solve the environmental issues such as pollution and emission of harmful gases by minimizing the excessive consumerism (Prothero et al., 2011). Heinrichs also say that collaborative consumption can reduce the use of resources and improve the collective cohesiveness (Heinrichs, 2013). Due to increasing awareness of negative environmental impact, people are likely to use products in order to have sustainable society (Gansky, 2010). Sustainability also motivates the supplier to share services (Bellotti et al., 2015). Thus, we can formulate the hypotheses as:

H3(a): Sustainability will positively affect the user intention to engage in peer-topeer sharing.

H3(b): Sustainability will positively affect the provider intention to engage in peer-to-peer sharing.

\subsection{Enjoyment}

Enjoyment is as important as economic benefits for taking part in sharing economy. People are motivated to participate in collaborative consumption because of the enjoyment they seek from the activity (Hamari et al., 2016). Enjoyment is the significant cause of user's participation in sharing economy by growing a positive attitude to use products or services (Hamari et al., 2016). Enjoyment refers to degree to which in peer-to-peer sharing is perceived to be enjoyable excepting any predicted performance results (Davis et al., 1992; Kim \& Min, 2015; Liu et al., 2015).

In fact people share their resources to perceive enjoyment (Widlok, 2004). Participation in sharing economy services provide the opportunity to interact with the members of society (Hwang \& Griffiths, 2017). Similarly enjoyment has a positive impact on consumer's intention to use peerto peer services (Tussyadiah, 2016; Sung et al., 2018). According to PwC's survey, more 
than 63 percent people responded that enjoyment motivates them to participate in sharing economy (PwC, 2015). Therefore, enjoyment is expected to play a key role in influencing the provider and user to participate in sharing economy (Botsman \& Rogers, 2010).

H4(a): Enjoyment will positively affect the provider intention to engage in peer-topeer sharing.

H4(b): Enjoyment will positively affect the user intention to participate in peer-topeer sharing.

\subsection{Social interaction}

Sharing economy provides the opportunities for social interaction (Sung et al., 2018). Researchers argues that collaborative economy helps the participants to start and maintain social relationship and become an effective part of the society and they have suggested that social interaction positively effects the users to participate in peer-to-peer sharing (Barnes \& Mattsson, 2017).

Albinsson and Yasanthi Perera say that social interaction and seeking friendship are the main drivers of participation in peer-topeer sharing (Albinsson \& Yasanthi Perera, 2012). Meeting new people, desire to connect with people, desire to become active part of the local society and helping others are some of the social motives for sharing resources (Botsman \& Rogers, 2010; Chudzian, 2015; Tussyadiah, 2015). The social relationship is the key factor that effects the user experience in sharing services (Priporas et al., 2017). The people use peer-to-peer sharing to seek social interaction with local people and the service provider (Tussyadiah \& Pesonen, 2016). Social connections can promote the participation in sharing economy services (Bellotti et al., 2015). According to Ikkala and Lampinen (2015), social inclusion keeps the service provider involved in sharing economy. Therefore, we hypothesized that:

H5(a): social interaction will positively affect the provider intention to engage in peer-to-peer sharing.

H5(b): social interaction will positively affect the user intention to engage in peer-topeer sharing.

\subsection{Indulgence}

Culture is the most influential factor which decides the way an individual behaves. The Hofstede cultural model has become a globally recognized model for studying and understanding the cultural differences. Due to its worldwide acceptance, this model has been applied in consumer research (Mazaheri et al., 2014; Tang, 2017; Gupta et al., 2019). In 2010, based on extensive work done by Hofstede and Michael Minkov, the 6th dimension of indulgence versus restraint was added to the original Hofstede's cultural model (Minkov \& Hofstede, 2012). Indulgence refers to the satisfaction of basic desires related to pleasure in life and entertainment (Hofstede, 2011). In indulgent societies, individuals are likely to be happier and enjoy their liberty (Maleki \& de Jong, 2014). A study found that Happiness in indulgent societies is greater than in restraint societies due to less restriction on liberty and enjoyment of individuals in indulgent societies (Minkov, 2009). 
Recently one study has examined the effect of cultural dimensions on individual's intention to engage in peer-to-peer sharing (Gupta et al., 2019). In which the researcher studied the effect of four cultural dimensions on provider's intention to provide and consumer's intention to rent but did not studied the indulgence value. Due to newness of this dimension, more studies are required for the applicability of this cultural dimension. In Indulgent society, individuals have freedom to express their positive emotions (Minkov, 2009). From consumer perspective, consumers from this culture give importance to leisure and enjoyment during purchase and consumption activity. Therefore, The tendency to enjoy lives and freedom influence the consumer behavior (Koc et al., 2017). Individuals with higher indulgence rating are more likely to enjoy and experience positive feelings to a greater extent. Thus, indulgence is expected to play a key role in influencing the provider and user to engage in peer-to-peer sharing.

H6(a): Indulgence cultural value will positively affect the provider intention to engage in peer-to-peer sharing.

H6(b): Indulgence cultural value will positively affect the user intention to engage in peer-to-peer sharing.

\section{RESEARCH MODEL}

Based on the hypotheses rationalized in literature, a research model has been developed as user and provider model to examine the impact of influencing factors (Figure 1).

\section{METHODOLOGY}

The Survey method was chosen to collect the quantitative data from participants of

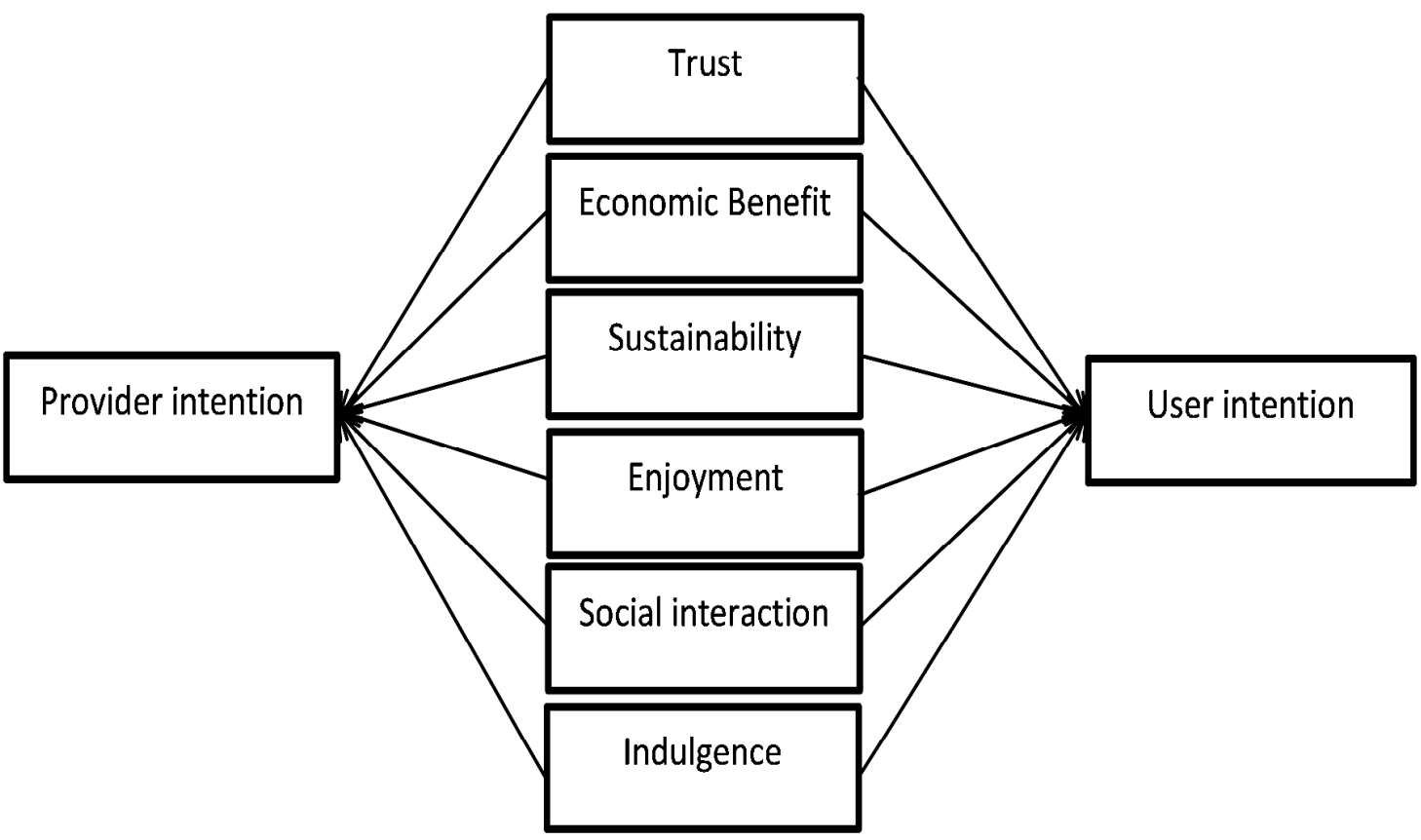

Figure 1. Research Framework 
sharing economy, in which the consumers and providers were included. This method was selected because it increases the generalizability of findings and considered as most appropriate method for in-depth investigation of a phenomenon (Dooley, 2001). The measurement items in survey were adopted from the already existing literature to secure the content validity. At the beginning of survey a definition of peerto-peer sharing was provided, the questionnaire was split into two segments, the first segment was designed to get demographic information of user and provider, the second part was designed to measure the constructs by using valid items and the five-point Likert scale was used for the items ranging from 1 to 5 . Table 3 describes all constructs and the valid items used for this study.

This study was conducted in Pakistan and selected two platforms based ride-hailing companies operating in Pakistan, Careem and Uber for data collection. Both of these

Table 3. Survey instruments

\begin{tabular}{|c|c|c|c|}
\hline Constructs & Items & Description & Sources \\
\hline Trust & Trust 1 & $\begin{array}{l}\text { In peer-to-peer sharing, the user/service provider is } \\
\text { trustworthy. } \\
\text { In peer-to-peer sharing, the user/provider is honest in its } \\
\text { dealings with the service provider/user. } \\
\text { In peer-to-peer sharing, the user/provider keeps its } \\
\text { commitments to its service provider/user. }\end{array}$ & $\begin{array}{l}\text { (Cheung et } \\
\text { al., 2015) }\end{array}$ \\
\hline Enjoyment & $\begin{array}{l}\text { Enjoyment } 1 \\
\text { Enjoyment } 2 \\
\text { Enjoyment } 3 \\
\text { Enjoyment } 4 \\
\text { Enjoyment } 5\end{array}$ & $\begin{array}{l}\text { I think peer-to-peer sharing is enjoyable. } \\
\text { I think peer-to-peer sharing is exciting. } \\
\text { I think peer-to-peer sharing is fun } \\
\text { I think peer-to-peer sharing is interesting. } \\
\text { I think peer-to-peer sharing is pleasant. }\end{array}$ & $\begin{array}{l}\text { (Van der } \\
\text { Heijden, } \\
\text { 2004) }\end{array}$ \\
\hline $\begin{array}{c}\text { Social } \\
\text { interaction }\end{array}$ & $\begin{array}{l}\text { Social interaction } 1 \\
\text { Social interaction } 2 \\
\text { Social interaction } 3 \\
\text { Social interaction } 4\end{array}$ & $\begin{array}{l}\text { Peer-to-peer sharing helps build a mutual bond with others. } \\
\text { Peer-to-peer sharing helps you maintain social relationship } \\
\text { with others. } \\
\text { Peer-to-peer sharing will make you feel connected with } \\
\text { people. } \\
\text { Peer-to-peer sharing helps strengthen social relations with } \\
\text { others. }\end{array}$ & $\begin{array}{c}\text { (Sung et al., } \\
\text { 2018) }\end{array}$ \\
\hline Sustainability & $\begin{array}{l}\text { Sustainability } 1 \\
\text { Sustainability } 2 \\
\text { Sustainability } 3 \\
\text { Sustainability } 4 \\
\text { Sustainability } 5 \\
\end{array}$ & $\begin{array}{l}\text { Peer-to-peer sharing helps save natural resources. } \\
\text { Peer-to-peer sharing is a sustainable mode of consumption. } \\
\text { Peer-to-peer sharing is ecological } \\
\text { Peer-to-peer sharing is environment-friendly. } \\
\text { Peer-to-peer sharing is efficient in terms of using energy. }\end{array}$ & $\begin{array}{l}\text { (Hamari et } \\
\text { al., 2016) }\end{array}$ \\
\hline $\begin{array}{c}\text { Economic } \\
\text { Benefit }\end{array}$ & $\begin{array}{l}\text { Economic } 1 \\
\text { Economic } 2\end{array}$ & $\begin{array}{l}\text { I can save money by participating in peer-to-peer sharing. } \\
\text { My participation in peer-to-peer sharing benefits me } \\
\text { financially. } \\
\text { My participation in peer-to-peer sharing can improve my } \\
\text { economic situation. } \\
\text { My participation in peer-to-peer sharing saves me time. }\end{array}$ & $\begin{array}{c}\text { (Bock et al., } \\
\text { 2005) }\end{array}$ \\
\hline Indulgence & $\begin{array}{l}\text { Indulgence } 1 \\
\text { Indulgence } 2 \\
\text { Indulgence } 3 \\
\end{array}$ & $\begin{array}{l}\text { People should be happy in everyday life. } \\
\text { People should have fun. } \\
\text { People should have freedom of speech }\end{array}$ & $\begin{array}{c}\text { (Wen et al., } \\
\text { 2018) }\end{array}$ \\
\hline Intention & Intention3 & $\begin{array}{l}\text { In peer-to-peer economy, I have an intention to use/provide } \\
\text { sharing services. } \\
\text { In peer-to-peer economy, I am willing to use/provide } \\
\text { sharing services. } \\
\text { In peer-to-peer economy, I am willing to spend time and } \\
\text { money to use/provide sharing services. }\end{array}$ & $\begin{array}{c}\text { (Jang et al., } \\
\text { 2015) }\end{array}$ \\
\hline
\end{tabular}


ride-hailing companies operates under sharing economy business that provides online platforms to connect the users to providers using their own non-commercial vehicles (Malik \& Wahaj, 2019) . In 2015, Careem started its business operation in Pakistan, while Uber was launched in 2016. The data was collected from both, the user and provider. Young people were preferred to collect the data due to the following two reasons. Firstly, in line with the previous studies on Peer-to-Peer sharing, it has been deeply observed that the millennial and the young consumers particularly use the sharing services or products and they are considered the active participants of collaborative consumption(Maycotte, 2015; Akbar et al., 2016; Godelnik, 2017). Secondly, according to the recent Human Development report on Pakistan (2018), claimed that currently more than $64 \%$ of the Pakistan's population is younger than 30 and approximately $29 \%$ of the nation is between the age of 15 and 19 . Further the report points to that Pakistan now has more young population than it has ever had and it is estimated that the percentage of young people will increase continuously until at least 2050. Therefore the university students and young users of Uber and Careem were recruited as participants. On the other side, to measure the peer providers' intention, the data was collected from the drivers of Uber and Careem. The convenience and simple random sampling technique were used in this study. The questionnaire was developed in English. The questionnaire was sent to the consumers through email and social media tools. The questionnaire was sent to almost 425 users and got 248 responses, out of which the incomplete responses were excluded and only 211 responses were used for statistical analysis. In addition, 206 questionnaires were disseminated among providers and got

Table 4. Socio demographic characteristics of Users and Providers

\begin{tabular}{lcccc}
\hline \multirow{2}{*}{ Variables } & \multicolumn{2}{c}{ Consumer (User) } & \multicolumn{2}{c}{ Provider } \\
\cline { 2 - 5 } Gender & Frequency & \% & Frequency & \% \\
Male & 113 & 53.6 & 178 & 100 \\
Female & 98 & 46.4 & 00 & 00 \\
\hline Age (years) & & & & \\
$18-25$ & 134 & 63.5 & 61 & 34.3 \\
$26-35$ & 65 & 30.8 & 80 & 44.9 \\
35-45 & 11 & 5.20 & 16 & 9.00 \\
45-55 & 0 & 0.00 & 12 & 6.70 \\
Above 55 & 1 & 0.50 & 9 & 5.10 \\
\hline Education & & & & \\
Masters or above & 98 & 46.4 & 35 & 19.7 \\
Bachelor & 90 & 42.7 & 64 & 36.0 \\
Basic education & 23 & 10.9 & 79 & 44.4 \\
\hline Household income per & & & & \\
month (in PKR) & 82 & 38.9 & 56 & 31.5 \\
Below 35000 & 58 & 27.5 & 47 & 26.4 \\
Between 35000 to 50,000 & 31 & 14.7 & 21 & 11.8 \\
Between 51,000 to 65,000 & 40 & 19.0 & 54 & 30.3 \\
Above 65,000 & & & & \\
\hline Marital status & 142 & 67.3 & 79 & 44.4 \\
Single & 69 & 32.7 & 99 & 55.6 \\
Married & & &
\end{tabular}


160 responses. Most of the questionnaire were got filled by sharing a ride with providers, out of which only 147 used for statistical analysis. The demographic characteristics of provider and user are given in Table 4.

The Statistical Package for Social Science (SPSS) and Analysis of a Moment Structure (AMOS) were used for data analysis. The reliability for each construct was calculated using SPSS statistics 25. In which the Cronbach's alpha value of each construct was measured to check the internal consistency (Cronbach, 1971), and all the values were over 0.7 , which is the general acceptance standard according to Hair et al., (2006). The composite reliability was acceptable as it was over 0.7 in each case. Hence the overall reliability is achieved, as the values of composite reliability and
Cronbach's alpha were over 0.7 (Reuterberg \& Gustafsson, 1992). The factor loadings of the measures were in between 0.66 to 0.85 and the value of average variance extracted range from 0.53 to 0.63 . The values are given in the Table 5 and Table 6.

The two-step analysis was performed as suggested by Hair et al., (2006). In the first part, the measurement model was examined by conducting confirmatory factor analysis to test the reliability, convergent and discriminant validity. In the second part, the structural model was built to test the interrelationship among the study variables. The model fit summary for the measurement model and the structural model is given in the Table 7, in which all values present an excellent fit for the models, as the values were over the general acceptance standard according to (Bagozzi \& Yi, 1988). A model

Table 5. Reliability and Validity Measures (User)

\begin{tabular}{|c|c|c|c|c|c|}
\hline Constructs & Items & Factor loading & Cronbach's $\alpha$ & $\mathbf{C R}$ & AVE \\
\hline \multirow{3}{*}{ Trust } & Trust 1 & 0.79 & \multirow{3}{*}{0.83} & \multirow{3}{*}{0.83} & \multirow{3}{*}{0.54} \\
\hline & Trust 2 & 0.82 & & & \\
\hline & Trust 3 & 0.76 & & & \\
\hline \multirow{4}{*}{ Enjoyment } & Enjoyment 1 & 0.72 & \multirow{4}{*}{0.86} & \multirow{4}{*}{0.87} & \multirow{4}{*}{0.62} \\
\hline & Enjoyment 2 & 0.81 & & & \\
\hline & Enjoyment 3 & 0.85 & & & \\
\hline & Enjoyment 4 & 0.78 & & & \\
\hline \multirow{4}{*}{$\begin{array}{c}\text { Social } \\
\text { interaction }\end{array}$} & Social interaction 1 & 0.71 & \multirow{4}{*}{0.85} & \multirow{4}{*}{0.86} & \multirow{4}{*}{0.60} \\
\hline & Social interaction 2 & 0.84 & & & \\
\hline & Social interaction 3 & 0.79 & & & \\
\hline & Social interaction 4 & 0.76 & & & \\
\hline \multirow{4}{*}{ Sustainability } & Sustainability 1 & 0.82 & \multirow{4}{*}{0.87} & \multirow{4}{*}{0.87} & \multirow{4}{*}{0.63} \\
\hline & Sustainability 2 & 0.84 & & & \\
\hline & Sustainability 3 & 0.75 & & & \\
\hline & Sustainability 4 & 0.76 & & & \\
\hline \multirow{4}{*}{$\begin{array}{c}\text { Economic } \\
\text { Benefit }\end{array}$} & Economic 1 & 0.79 & \multirow{4}{*}{0.81} & \multirow{4}{*}{0.82} & \multirow{4}{*}{0.53} \\
\hline & Economic 2 & 0.75 & & & \\
\hline & Economic 3 & 0.71 & & & \\
\hline & Economic 4 & 0.67 & & & \\
\hline \multirow{3}{*}{ Indulgence } & Indulgence 1 & 0.75 & \multirow{3}{*}{0.79} & \multirow{3}{*}{0.80} & \multirow{3}{*}{0.62} \\
\hline & Indulgence 2 & 0.88 & & & \\
\hline & Indulgence 3 & 0.66 & & & \\
\hline \multirow{3}{*}{ Intention } & Intention 1 & 0.71 & \multirow{3}{*}{0.77} & \multirow{3}{*}{0.78} & \multirow{3}{*}{0.58} \\
\hline & Intention 2 & 0.75 & & & \\
\hline & Intention 3 & 0.74 & & & \\
\hline
\end{tabular}


Table 6. Reliability and Validity Measures (Provider)

\begin{tabular}{|c|c|c|c|c|c|}
\hline Constructs & Items & Factor loading & Cronbach's $\alpha$ & CR & AVE \\
\hline \multirow{3}{*}{ Trust } & Trust 1 & 0.76 & \multirow{3}{*}{0.77} & \multirow{3}{*}{0.77} & \multirow{3}{*}{0.52} \\
\hline & Trust 2 & 0.81 & & & \\
\hline & Trust 3 & 0.63 & & & \\
\hline \multirow{4}{*}{ Enjoyment } & Enjoyment 1 & 0.78 & \multirow{4}{*}{0.88} & \multirow{4}{*}{0.88} & \multirow{4}{*}{0.66} \\
\hline & Enjoyment 2 & 0.82 & & & \\
\hline & Enjoyment 3 & 0.87 & & & \\
\hline & Enjoyment 4 & 0.80 & & & \\
\hline \multirow{4}{*}{$\begin{array}{c}\text { Social } \\
\text { interaction }\end{array}$} & Social interaction 1 & 0.74 & \multirow{4}{*}{0.86} & \multirow{4}{*}{0.87} & \multirow{4}{*}{0.63} \\
\hline & Social interaction 2 & 0.87 & & & \\
\hline & Social interaction 3 & 0.84 & & & \\
\hline & Social interaction 4 & 0.74 & & & \\
\hline \multirow{4}{*}{ Sustainability } & Sustainability 1 & 0.80 & \multirow{4}{*}{0.86} & \multirow{4}{*}{0.86} & \multirow{4}{*}{0.61} \\
\hline & Sustainability 2 & 0.83 & & & \\
\hline & Sustainability 3 & 0.75 & & & \\
\hline & Sustainability 4 & 0.77 & & & \\
\hline \multirow{4}{*}{$\begin{array}{c}\text { Economic } \\
\text { Benefit }\end{array}$} & Economic 1 & 0.80 & \multirow{4}{*}{0.82} & \multirow{4}{*}{0.82} & \multirow{4}{*}{0.54} \\
\hline & Economic 2 & 0.73 & & & \\
\hline & Economic 3 & 0.71 & & & \\
\hline & Economic 4 & 0.70 & & & \\
\hline \multirow{3}{*}{ Indulgence } & Indulgence 1 & 0.76 & \multirow{3}{*}{0.82} & \multirow{3}{*}{0.83} & \multirow{3}{*}{0.62} \\
\hline & Indulgence 2 & 0.90 & & & \\
\hline & Indulgence 3 & 0.70 & & & \\
\hline \multirow{3}{*}{ Intention } & Intention 1 & 0.71 & \multirow{3}{*}{0.76} & \multirow{3}{*}{0.77} & \multirow{3}{*}{0.52} \\
\hline & Intention 2 & 0.74 & & & \\
\hline & Intention 3 & 0.73 & & & \\
\hline
\end{tabular}

is said to be good fit if the values of CFI is over 0.8; Tucker-Lewis coefficient is over 0.9 and RMSEA is up to 0.08 (Byrne, 2010).

Table 7. User and provider research model fit

\begin{tabular}{ccc}
\hline \multicolumn{3}{c}{ (Measurement Model) } \\
\hline Index & $\begin{array}{c}\text { Value } \\
\text { (User) }\end{array}$ & $\begin{array}{c}\text { Value } \\
\text { (Provider) }\end{array}$ \\
\hline GFI & 0.81 & 0.81 \\
AGFI & 0.75 & 0.76 \\
CFI & 0.87 & 0.90 \\
TLI & 0.85 & 0.87 \\
RMSEA & 0.08 & 0.07 \\
\hline
\end{tabular}

\section{RESULTS}

The results, after testing the study hypotheses by using structure equation modeling (SEM) reveal that indulgence is the significant correspondent of user intention to participate in peer-to-peer sharing with an estimate value of 0.24 . A strong relationship was also found in this study between economic benefits and user intention with an estimate value of 0.35 . Enjoyment and user intention were positively associated with an estimate value of 0.10 . Social interaction was also found to be a significant predictor of user intention to rent in peer-to-peer sharing with an estimate value of 0.26 . However, the no significant relationship was found among trust, sustainability and user intention to participate in sharing economy. The estimate values and significance values can be found in Table 8.

All hypotheses except sustainability were supported in the case of provider. A strong association was found between economic 
benefits and provider intention to rent out with an estimate value of 0.32 . Similarly the results show a strong relationship of social interaction, enjoyment and indulgence with the provider intention to rent out in peer-topeer sharing with an estimate value of 0.30 , 0.13 , and 0.28 respectively. The estimate value and significance values are given in the Table 9.

\section{CONCLUSIONS AND DISCUSSION}

Sharing economy is a fascinating concept, offering a distinctive model where people can not only use the services but also provide the services to others (Gupta et al., 2019). In the past, the researchers have conducted several studies and suggested the factors, such as hedonic, social and economic

Table 8. Hypotheses testing (User)

\begin{tabular}{cllccc}
\hline Hypothesis & \multicolumn{1}{c}{ Statement } & Estimate & Significance & Results \\
\hline H1a & $\begin{array}{l}\text { Trust in provider will positively affect the user } \\
\text { intention to engage in peer-to-peer sharing. }\end{array}$ & 0.07 & 0.18 & $\begin{array}{c}\text { Not } \\
\text { Supported }\end{array}$ \\
\hline H2a & $\begin{array}{l}\text { Economic benefit will positively affect the } \\
\text { user intention to engage in peer-to-peer } \\
\text { sharing. }\end{array}$ & 0.35 & 0.001 & Supported \\
\hline H3a & $\begin{array}{l}\text { Sustainability will positively affect the user } \\
\text { intention to engage in peer-to-peer sharing. }\end{array}$ & 0.06 & 0.12 & $\begin{array}{c}\text { Not } \\
\text { supported }\end{array}$ \\
\hline H4a & $\begin{array}{l}\text { Enjoyment will positively affect the user } \\
\text { intention to engage in peer-to-peer sharing. }\end{array}$ & 0.10 & 0.03 & Supported \\
\hline H5a & $\begin{array}{l}\text { Social interaction will positively affect the } \\
\text { user intention to engage in peer-to-peer } \\
\text { sharing. }\end{array}$ & 0.26 & 0.001 & Supported \\
\hline H6a & $\begin{array}{l}\text { Indulgence cultural value will positively affect } \\
\text { the user intention to engage in peer-to-peer } \\
\text { sharing. }\end{array}$ & 0.24 & 0.001 & Supported \\
\hline
\end{tabular}

Table 9. Hypothesis testing (Provider)

\begin{tabular}{clccc}
\hline Hypothesis & \multicolumn{1}{c}{ Statement } & Estimate & Significance & Results \\
\hline H1b & $\begin{array}{l}\text { Trust in user will positively affect the provider } \\
\text { intention to engage in peer-to-peer sharing. }\end{array}$ & 0.038 & 0.04 & Supported \\
\hline H2b & $\begin{array}{l}\text { Economic benefit will positively affect the } \\
\text { provider intention to engage in peer-to-peer } \\
\text { sharing. }\end{array}$ & 0.32 & 0.001 & Supported \\
\hline H3b & $\begin{array}{l}\text { Sustainability will positively affect the } \\
\text { provider intention to engage in peer-to-peer } \\
\text { sharing. }\end{array}$ & 0.02 & 0.73 & $\begin{array}{c}\text { Not } \\
\text { supported }\end{array}$ \\
\hline H4b & $\begin{array}{l}\text { Enjoyment will positively affect the provider } \\
\text { intention to engage in peer-to-peer sharing. }\end{array}$ & 0.13 & 0.03 & Supported \\
\hline H5b & $\begin{array}{l}\text { Social interaction will positively affect the } \\
\text { provider intention to engage in peer-to-peer } \\
\text { sharing. }\end{array}$ & 0.30 & 0.001 & Supported \\
\hline H6b & $\begin{array}{l}\text { Indulgence cultural value will positively affect } \\
\text { the provider intention to engage in peer-to- } \\
\text { peer sharing. }\end{array}$ & 0.28 & 0.001 & Supported \\
\hline
\end{tabular}


benefits can motivate the consumer to participate in peer-to-peer sharing (Botsman \& Rogers, 2010; Möhlmann, 2015). However providers' intention to rent out in peer-to-peer economy has not been studied majority of the extent. A few studies have covered the provider's perspective, e.g. (Böcker \& Meelen, 2017). In order to have a deeper comprehension of peer-to-peer sharing, this paper studies the both, the provider and the user intention to participate in sharing economy. The findings of this study provide some potentially significant insights. The current study is the first to examine the Impact of indulgence cultural value on providers and consumers' intention to participate in sharing economy. As suggested by Hofstede (2011), the cultures based on restraint value are likely to control their desires and gratification needs. While in the indulgence based cultures, people do not control their impulses and they seek pleasure by having fun in life (Wen et al., 2018). According to Hofstede country comparison scale, Pakistan's culture is based on restraint value with zero score on indulgence value. It depicts that the Pakistani society is restrained (Minkov \& Hofstede, 2012). The findings of this study reveal a significant impact of indulgence on user as well as providers' intention to participate in sharing economy. The findings of current study suggest that an individual from a highly indulgent culture will be more interested in peer-to-peer sharing economy services. Individuals from societies scoring high at indulgence are more likely to have enjoyment and positive feelings. According to Bucher et al., (2016), hedonic motivation plays a significant role in determining sharing behavior. Thus, in Pakistan, individuals may participate in peer-to-peer sharing economy because sharing services provides them an opportunity for enjoyment and entertainment. Further, People in Pakistan, specially the youth do not control their impulses and desires, they are less restrained by the social norm, they like to enjoy their lives and seek pleasure in routine activities. It has also been observed in the study that the enjoyment is also a significant predictor of user and providers intention to participate in sharing economy. The result lends support from the previous research (Tussyadiah, 2016; Hwang \& Griffiths, 2017). It means that the Pakistani society is not purely a restrained society. However, the same finding is contradictory to the results of previous study in case of provider's model (Sung et al., 2018). Further, the findings predicted a significant association among the economic benefit, user and providers' intention to participate in sharing economy. In case of user model, the result contradicts to the findings of previous study and lends support in case of provider's model (Sung et al., 2018).

Moreover, this study has found no significant relationship among sustainability, consumers' intention and providers' intention to participate in peer to peer economy. In case of providers' model, this finding is contradictory to the findings of previous studies (Böcker \& Meelen, 2017). In case of consumer model, the result are in contrast to previous research.(Guttentag, 2015). As suggested by Eckhardt et al., (2010), there are three major reasons of nonsustainable behavior: economic reasons, institutional reasons and developmental reasons. With regard to sustainability, may be the same reasons also apply in sharing economy. This study has found no significant association between the trust in provider and consumer intention to use services in sharing economy, this finding 
contradicts to the previous research findings (Hawlitschek et al., 2016a). In case of provider's model, we found a strong association between provider's trust in consumer and provider intention to rent out services. Previous studies suggest that in peer to peer sharing the service provider may have concerns regarding the safety of shared resources. In sharing economy transaction is hard to achieve without the provider's trust in user peer. This finding lends support from the findings of previous research (Hawlitschek et al., 2016a). Further the social intearction was found as a significant predictor of both, the providers' and the consumers' intention to participate in peerto-peer sharing. The result is in line with the findings of previous research that studied social relationship (Karlsson \& Dolnicar, 2016; Böcker \& Meelen, 2017). This result makes sense because as suggested by (Hofstede, 2011), pakistani society is based on collectivism, where people socially interact with each other and strengthen the social bonding.

\subsection{Limitations and Future research}

This study has certain considerations and the findings of the study should be presented with caution. First, the data for the research were collected in Pakistan. Therefore it is possible that the findings may not be generalized for countries other than Pakistan. For further validation and generalizability, the model of this research should be studied in other countries. Future studies should conduct longitudinal studies and examine the impact of factors changes over time. Future studies should consider the indulgencerestraint cultural value to increase the applicability of this value across the different cultures. Further, the researchers should conduct more empirical research to examine the consumer-provider model to develop a deeper understanding. The future research can study consumer-provider model by linking the self-construal with collectivism vs. individualism cultural dimension, moreover the relation between collaborative consumption and subjective well-being would be studied in future.

\section{References}

Akbar, P., Mai, R., \& Hoffmann, S. (2016). When do materialistic consumers join commercial sharing systems. Journal of Business Research, 69 (10), 4215-4224.

Albinsson, P.A., \& Yasanthi Perera, B. (2012). Alternative marketplaces in the 21st century: Building community through sharing events. Journal of Consumer Behaviour, 11 (4), 303-315.

Aloni, E. (2016). Pluralizing the 'Sharing' Economy. Washington Law Review, 91, 1397-1459.

Bagozzi, R.P., \& Yi, Y. (1988). On the evaluation of structural equation models. Journal of the Academy of Marketing Science, 16 (1), 74-94.

Barbu, C.M., Florea, D.L., Ogarcă, R.F., \& Barbu, M.C.R. (2018). From Ownership to Access: How the Sharing Economy is Changing the Consumer Behavior. Amfiteatru Economic, 20 (48), 373-387.

Bardhi, F., \& Eckhardt, G.M. (2012). Access-based consumption: The case of car sharing. Journal of consumer research, 39,(4), 881-898.

Barnes, S.J., \& Mattsson, J. (2017). Understanding collaborative consumption: Test of a theoretical model. Technological Forecasting and Social Change, 118 (c), 281292. 


\title{
ЕРА ЕКОНОМИЈЕ ДЕЉЕЊА: ФАКТОРИ КОЈИ УТИЧУ НА НАМЕРЕ ПОНАШАЫА КОРИСНИКА И ДОБАВЉАЧА ДА УЧЕСТВУ ЈУ У ЕКОНОМИЈИ “PEER-TO-PEЕR"
}

\author{
Aleem Raza, Muhammad Asif, Samia Ayyub
}

\section{Извод}

Економија дељења је социо-економски модел који се најбрже развија и о коме се често расправља. У економији дељења заснованој на платформи, добављач пружа услугу, а потрошач користи услугу са двостраног тржишта. Међутим, недостају студије које би покривале обе стране тржишта дељења заснованог на платформи. Ова студија има за циљ да испита учинак попуштања, поверења, економске користи, социјалне интеракције, уживања и одрживости на намеру корисника и добављача да се укључе у „peer-to-peer“ дељење. Ово експланаторно истраживање користи квантитативну методологију која укључује прикупљање података путем структурираног упитника од корисника услуга $($ н $=220)$ и пружалаца услуга $($ н $=170)$ Убера и Царема усвајањем технике узорковања грудве снега. Моделирање структурираних једначина (Structured Equation Modeling- SEM) примењено је за анализу података коришћењем AMOC 24. Емпиријски резултати ове студије показују да попустљивост, социјална интеракција, економска корист и уживање имају значајну позитивну повезаност са намером корисника и добављача. Даље, утврђена је позитивна веза између поверења провајдера у корисника и намере провајдера да се укључи у „реer-to-peer“дељење. Ова студија даје свој значајан допринос пружајући нове увиде у литературу и праксу проучавањем двостраног тржишта. Поред тога, студија је истраживала утицај попуштања на намеру ,peer-to-peer“"размене, коју у литератури тек треба истражити. Ова студија сугерише практичне импликације за менаџере маркетинга на развијање ефикасних пословних стратегија платформи и маркетиншких кампања у складу са намером појединаца да се укључе у размену.

Кључне речи: економија дељења, „peer-to-peer“ дељење, намера, попустљивост, одрживост, економске користи, социјална интеракција

Bartenberger, M., \& Leitner, P. (2013). motivation for using peer-to-peer economy Crowdsourcing and crowdfunding: systems. Proceedings of the 33rd Annual approaches to foster social innovation. ACM Conference on Human Factors in Proceedings of the IADIS international Computing Systems, Seoul Republic of conference web based communities and Korea. 1085-1094. social media 2013, Prague, Czech Republic.

Belk, R. (2007). Why not share rather than own? The Annals of the American Academy of Political and Social Science, 611 (1), 126-140.

Bellotti, V., Ambard, A., Turner, D., Gossmann, C., Demkova, K., \& Carroll, J. M. (2015). A muddle of models of

Bock, G.W., Zmud, R.W., Kim, Y., \& Lee, J. (2005). Behavioral intention formation in knowledge sharing: Examining the roles of extrinsic motivators, socialpsychological factors, and organizational climate. MIS quarterly, 29 (1), 87-111.

Böcker, L., \& Meelen, T. (2017). Sharing for people, planet or profit? Analysing 
motivations for intended sharing economy participation. Environmental Innovation and Societal Transitions, 23, 28-39.

Botsman, R., \& Rogers, R. (2010). Whats mine is yours: The rise of collaborative consumption. Harper Business: New York, NY, USA.

Bucher, E., Fieseler, C., \& Lutz, C. (2016). What's mine is yours (for a nominal fee)-Exploring the spectrum of utilitarian to altruistic motives for Internet-mediated sharing. Computers in Human Behavior, 62, 316-326.

Byrne, B.M. (2010). Structural equation modeling with AMOS: basic concepts, applications, and programming ( 2 nd Ed). Taylor \& Francis Group, New York.

Chen, L. (2015). At $\$ 68$ billion valuation, Uber will be bigger than GM, Ford, and Honda. Forbes. Retrieved from: https://www.forbes.com/sites/liyanchen/201

5/12/04/at-68-billion-valuation-uber-willb e - b i g g e r - t h a n - g m - ford - a n d honda/?sh=798776b732e3

Cheng, M. (2016). Sharing economy: A review and agenda for future research. International Journal of Hospitality Management, 57, 60-70.

Cheung, C., Lee, Z., \& Chan, T. (2015). Self-disclosure in social networking sites: the role of perceived cost, perceived benefits and social influence. Internet Research, 25 (2), 279-299.

Chudzian, J. (2015). Importance of economic and noneconomic factors in collaborative consumption. Ekonomia i Zarządzanie, 7 (4), 14-22.

Chui, M., Manyika, J., Bughin, J., Dobbs, R., Roxburgh, C., Sarrazin, H., Sands, G., \& Westergren, M. (2012). The social economy: Unlocking value and productivity through social technologies. McKinsey Global Institute.
Cockayne, D.G. (2016). Sharing and neoliberal discourse: The economic function of sharing in the digital on-demand economy. Geoforum, 77, 73-82.

Cronbach, L.J. (1971). Test Validation. In Thorndike, R. (Ed.), Educational Measurement (2nd ed.). American Council on Education. Washington, DC. 443-507

Cusumano, M.A. (2015). How traditional firms must compete in the sharing economy. Communications of the ACM, 58 (1), 3234.

Davis, F. D., Bagozzi, R.P., \& Warshaw, P.R. (1992). Extrinsic and intrinsic motivation to use computers in the workplace 1. Journal of applied social psychology, 22 (14), 1111-1132.

Dooley, D. (2001). Social Research Methods. Prentice Hall. Upper Saddle River, NJ.

Eckhardt, G.M., Belk, R., \& Devinney, T.M. (2010). Why don't consumers consume ethically? Journal of Consumer Behaviour, 9 (6), 426-436.

Efthymiou, D., Antoniou, C., \& Waddell, P. (2013). Factors affecting the adoption of vehicle sharing systems by young drivers. Transport policy, 29 (c), 64-73.

Frenken, K., \& Schor, J. (2017). Putting the sharing economy into perspective. Environmental Innovation and Societal Transitions, 23, 3-10.

Ganapati, S., \& Reddick, C.G. (2018). Prospects and challenges of sharing economy for the public sector. Government Information Quarterly, 35 (1), 77-87.

Gansky, L. (2010). The mesh: Why the future of business is sharing, Penguin Group, London, England.

Godelnik, R. (2017). Millennials and the sharing economy: Lessons from a 'buy nothing new, share everything month'project. Environmental Innovation 
and Societal Transitions, 23 (c), 40-52.

Gupta, M., Esmaeilzadeh, P., Uz, I., \& Tennant, V.M. (2019). The effects of national cultural values on individuals' intention to participate in peer-to-peer sharing economy. Journal of business research, 97, 20-29.

Guttentag, D. (2015). Airbnb: disruptive innovation and the rise of an informal tourism accommodation sector. Current issues in Tourism, 18 (12), 1192-1217.

Guttentag, D., Smith, S., Potwarka, L., \& Havitz, M. (2018). Why tourists choose Airbnb: A motivation-based segmentation study. Journal of Travel Research, 57 (3), 342-359.

Habibi, M.R., Davidson, A., \& Laroche, M. (2017). What managers should know about the sharing economy. Business Horizons, 60 (1), 113-121.

Hair, J., Black, W., Babin, B., Anderson, R., \& Tatham, R. (2006). Multivariate Data Analysis (6th ed.). Pearson Prentice Hall. Upper Saddle River, NJ.

Hamari, J., Sjöklint, M., \& Ukkonen, A. (2016). The sharing economy: Why people participate in collaborative consumption. Journal of the association for information science and technology, 67 (9), 2047-2059.

Hathaway,I. \& Muro, M. (2016). Tracking the gig economy: New numbers. Brookings Report, 13.

Hawlitschek, F., Teubner, T., \& Gimpel, H. (2016a). Understanding the sharing economy-Drivers and impediments for participation in peer-to-peer rental. 49th Hawaii International Conference on System Sciences (HICSS), Kauai, USA.

Hawlitschek, F., Teubner, T., \& Weinhardt, C. (2016b). Trust in the sharing economy. Die Unternehmung, 70 (1), 26-44.

Heinrichs, H. (2013). Sharing economy: a potential new pathway to sustainability.
GAIA-Ecological Perspectives for Science and Society, 22 (4), 228-231.

Hirsch, P.M., \& Levin, D.Z. (1999). Umbrella advocates versus validity police: A life-cycle model. Organization Science, 10 (2), 199-212.

Hofstede, G. (2011). Dimensionalizing cultures: The Hofstede model in context. Online readings in psychology and culture, 2 (1), 8.

Huang, M.-H., \& Rust, R.T. (2011). Sustainability and consumption. Journal of the Academy of Marketing Science, 39 (1), 40-54.

Hwang, J., \& Griffiths, M.A. (2017). Share more, drive less: Millennials value perception and behavioral intent in using collaborative consumption services. Journal of Consumer Marketing, 34 (2), 132-146.

Ikkala, T., \& Lampinen, A. (2015). Monetizing network hospitality: hospitality and sociability in the context of Airbnb. CSCW'15 Proceedings of the ACM 2015 conference on Computer supported cooperative work. New York, ACM. 10331044

Jang, S.Y., Chung, J.Y., \& Kim, Y.G. (2015). Effects of environmentally friendly perceptions on customers' intentions to visit environmentally friendly restaurants: An extended theory of planned behavior. Asia Pacific Journal of Tourism Research, 20 (6), 599-618.

John, N.A. (2013). The social logics of sharing. The Communication Review, 16 (3), 113-131.

Karlsson, L., \& Dolnicar, S. (2016). Someone's been sleeping in my bed" Annals of Tourism Research, 58 (c), 159-162.

Kim, B., \& Min, J. (2015). The distinct roles of dedication-based and constraintbased mechanisms in social networking sites. Internet Research, 25 (1), 30-51. 
Kim, D.J., Ferrin, D.L., \& Rao, H.R. (2009). Trust and satisfaction, two stepping stones for successful e-commerce relationships: A longitudinal exploration. Information systems research, 20 (2), 237257.

Koc, E., Ar, A.A., \& Aydin, G. (2017). The potential implications of indulgence and restraint on service encounters in tourism and hospitality. Ecoforum Journal, 6 (3), 111.

Lamberton, C.P., \& Rose, R.L. (2012). When is ours better than mine? A framework for understanding and altering participation in commercial sharing systems. Journal of marketing, 76(4), 109-125.

Leonard, L.N. (2012). Attitude influencers in $\mathrm{C} 2 \mathrm{C}$ e-commerce: Buying and selling. Journal of Computer Information Systems, 52 (3), 11-17.

Liang, L.J., Choi, H.C., \& Joppe, M. (2018). Understanding repurchase intention of Airbnb consumers: perceived authenticity, electronic word-of-mouth, and price sensitivity. Journal of Travel \& Tourism Marketing, 35 (1), 73-89.

Liu, F., Zhao, X., Chau , P.Y.K., \& Tang, Q. (2015). Roles of perceived value and individual differences in the acceptance of mobile coupon applications. Internet Research, 25 (3), 471-495.

Maleki, A., \& de Jong, M. (2014). A proposal for clustering the dimensions of national culture. Cross-Cultural Research, 48 (2), 107-143.

Malik, F., \& Wahaj, Z. (2019). Sharing economy digital platforms and social inclusion/exclusion: A research study of Uber and Careem in Pakistan. In: Nielsen P., Kimaro H.C. (eds) Information and Communication Technologies for Development. Strengthening SouthernDriven Cooperation as a Catalyst for
ICT4D. ICT4D 2019. IFIP Advances in Information and Communication Technology, 551. Springer, Cham. 248-259.

Mao, Z., \& Lyu, J. (2017). Why travelers use Airbnb again? An integrative approach to understanding travelers' repurchase intention. International Journal of Contemporary Hospitality Management, 29 (9), 2464-2482.

Martin, E.W., \& Shaheen, S.A. (2011). Greenhouse gas emission impacts of carsharing in North America. IEEE transactions on intelligent transportation systems, 12 (4), 1074-1086.

Maycotte, H.O. (2015). Millennials are driving the Sharing Economy-And So Is Big Data. Retrieved from https://www. $\begin{array}{llllll}f & 0 & r & b & e & s\end{array}$. com/sites/homaycotte/2015/05/05/millennial s-are-driving-the-sharing-economy-and-so-i s-big-data.

Mazaheri, E., Richard, M.O., Laroche, M., \& Ueltschy, L.C. (2014). The influence of culture, emotions, intangibility, and atmospheric cues on online behavior. Journal of Business Research, 67 (3), 253-259.

Minkov, M. (2009). Predictors of differences in subjective well-being across 97 nations. Cross-Cultural Research, 43 (2), 152-179.

Minkov, M., \& Hofstede, G. (2012). Hofstede's fifth dimension: New evidence from the World Values Survey. Journal of cross-cultural psychology, 43 (1), 3-14.

Möhlmann, M. (2015). Collaborative consumption: determinants of satisfaction and the likelihood of using a sharing economy option again. Journal of Consumer Behaviour, 14 (3), 193-207.

Morgan, R.M., \& Hunt, S.D. (1994). The commitment-trust theory of relationship marketing. Journal of Marketing, 58 (3), 2038. 
Mulcahy, D. (2016). The gig economy: the complete guide to getting better work, taking more time off, and financing the life you want. Amacom, New York, NY.

Parker, G.G., Van Alstyne, M.W., \& Choudary, S.P. (2016). Platform Revolution: How Networked Markets are Transforming the Economy and How to Make them to Work for you (1st edition), WW Norton \& Company, New York.

Pavlou, P.A., \& Fygenson, M. (2006). Understanding and predicting electronic commerce adoption: An extension of the theory of planned behavior. MIS quarterly, 30 (1), 115-143.

Perfili, M., Parente, S., Grimaldi, M., \& Morales-Alonso, G. (2019). A Study on Consumer Behaviour in the Sharing Economy. In Ortiz Bas, Á., Andrés Romano, C., Poler, R., García-Sabater, J.-P. (Eds.). Engineering Digital Transformation, Proceedings of the 11th International Conference on Industrial Engineering and Industrial Management. Springer, 79-86.

Priporas, C.V., Stylos, N., Rahimi, R., \& Vedanthachari, L.N. (2017). Unraveling the diverse nature of service quality in a sharing economy: A social exchange theory perspective of Airbnb accommodation. International Journal of Contemporary Hospitality Management, 29 (9), 22792301.

Prothero, A., Dobscha, S., Freund, J., Kilbourne, W.E., Luchs, M.G., Ozanne, L.K., \& Thøgersen, J. (2011). Sustainable consumption: Opportunities for consumer research and public policy. Journal of Public Policy \& Marketing, 30 (1), 31-38.

PWC, U. 2015. The sharing economysizing the revenue opportunity. Acessado em outubro/: https://www. pwc. co. uk/issues/megatrends/collisions/sharingecon omy/outlook-for-thesharing-economy-in- the-uk-. html.

Reuterberg, S.-E., \& Gustafsson, J.-E. (1992). Confirmatory factor analysis and reliability: Testing measurement model assumptions. Educational and Psychological Measurement, 52 (4), 795-811.

Rysman, M. (2009). The economics of two-sided markets. Journal of economic perspectives, 23 (3), 125-143.

Stephany, A. (2015). The business of sharing: Making it in the new sharing economy, Palgrave Macmillan, London.

Stokes, K., Clarence,E., Anderson, L., \& Rinne, A. (2014). Making sense of the UK collaborative economy. Nesta, London, UK.

Sundararajan, A. (2016). The sharing economy: The end of employment and the rise of crowd-based capitalism. Mit Press, US, UK.

Sung, E., Kim H., \& Lee, D. (2018). Why Do People Consume and Provide Sharing Economy Accommodation?-A Sustainability Perspective. Sustainability, 10 (6), 2072.

Tang, L. (2017). Mine your customers or mine your business: the moderating role of culture in online word-of-mouth reviews. Journal of International Marketing, 25 (2), 88-110.

Teubner, T., Adam, M.T.P., Camacho, S., \& Hassanein, K. (2014). Understanding resource sharing in $\mathrm{C} 2 \mathrm{C}$ platforms: the role of picture humanization, 25th Australasian Conference on Information Systems. Auckland, New Zealand.

Tussyadiah, I.P. (2015). An exploratory on drivers and deterrents of collaborative consumption in travel. In Tussyadiah, I., Inversini, A. (Eds.), Information \& Communication Technologies in Tourism 2015. Springer International Publishing, Switzerland.

Tussyadiah, I.P. (2016). Factors of 
satisfaction and intention to use peer-to-peer accommodation. International Journal of Hospitality Management, 55, 70-80.

Tussyadiah, I.P., \& Pesonen, J. (2016). Impacts of peer-to-peer accommodation use on travel patterns. Journal of Travel Research, 55 (8), 1022-1040.

van de Glind, P.B. (2013). The consumer potential of Collaborative Consumption (Master thesis). University of Utrecht, Faculty of Geosciences Theses, Netherlands

Van der Heijden, H. (2004). User acceptance of hedonic information systems. MIS quarterly, 28 (4), 695-704.

Villasenor, J., West, D. \& Lewis, R. 2015. The 2015 Brookings financial and digital inclusion project report: Measuring progress on financial access and usage, Brookings Institution Press.

Weber, T.A. (2014). Intermediation in a sharing economy: insurance, moral hazard, and rent extraction. Journal of Management Information Systems, 31 (3), 35-71.

Wen, J., Hu Y., \& Kim, H.J. (2018). Impact of individual cultural values on hotel guests' positive emotions and positive eWOM intention: Extending the cognitive appraisal framework. International Journal of Contemporary Hospitality Management, 30 (3), 1769-1787.

Widlok, T. (2004). Sharing by default? Outline of an anthropology of virtue. Anthropological Theory, 4 (1), 53-70.

Yaraghi, N., \& Ravi, S. (2017). The current and future state of the sharing economy. SSRN. Retrieved from: https://ssrn.com/abstract=3041207.

Zervas, G., Proserpio, D.M., \& Byers, J. (2017). The rise of the sharing economy: Estimating the impact of Airbnb on the hotel industry. Journal of marketing research, 54 (5), 687-705. 